\title{
Minimize the impact of waste pollution in ship repair processes to Improving Shipyard Industrial Infrastructure Sustainability
}

\author{
Rachmat Ashari ${ }^{1}$, Emil Budianto ${ }^{2}$, Herdis Herdiansyah $^{1 *}$, Mahawan Karuniasa ${ }^{1}$, and Putri A Saragi ${ }^{1}$ \\ ${ }^{1}$ School of Environmental Science, Universitas Indonesia, Salemba, Indonesia \\ ${ }^{2}$ Department of Chemistry, Universitas Indonesia, Depok, Indonesia
}

\begin{abstract}
Increasing the number of ship repair that make improvements it can be ensured that the greater the level of pollution will occur. Facilities (Infrastructure) is very helpful to minimize the pollution that will occur when ship repair. If the conditions of Infrastructure make it possible to flourish nowadays, which will further improve environmental performance. Development to improve domestic shipyard Infrastructure sustainability is very importance since $20 \%$ of national ship repair is still undertaken in foreign shipyard. This indicates that the ability of national shipyards still need to be improved especially in the infrastructure and facilities sector as production supports. This paper used data sample was undertaken in State-Owned Shipyard industry located in North Jakarta. Data analysis was undertaken starting from the ship entry, repair process until the accomplishment of ship repair. This research is testing the chemical impacts with related chemical parameters around the shipyard. the results showed that dangerous chemical concentrations were located around the shipyard and threatened the surrounding aquatic ecosystems. there needs to be management of shipbuilding infrastructure management that can minimize hazardous waste, especially basic storage. Basically the improvement of shipyard infrastructure can be undertaken if the ship repair process keeps increasing.
\end{abstract}

Keywords: waste pollution; ship repair; Infrastucture; sustainability.

\section{Introduction}

The ship is a marine transportation means that will at times be damaged either the construction or other parts of the vessel as a result of the operation or other influences such as environment or accident. In order to keep the vessel's condition optimally and the equipment contained in the vessel still meets the requirements set by the class or the classification agency used, it is necessary to make reparations, maintenance and maintenance on a regular basis. The role of shipyard industry engaged in reparations, in terms of reparation, maintenance and maintenance [1].

The shipbuilding industry can basically be divided into two major parts, namely shipbuilding and ship repairs. The two major parts always require a process of activity that includes the stages of material counting, production equipment, labor, cost, infrastructure and environment. Besides, the series of activities process has risks of environmental pollution [2] especially during the ship repair process.

Increased ship reparation activity causes increased sea pollution. Water is an object highly susceptible to pollution in addition to air and soil. Pollution is something that is not desirable and in an amount that exceeds the limit [3]. Environmental pollution is the entry or inclusion of living beings, energy, substances and / or components that exist in the environment, so that the quality of the environment may decrease to some extent, causing the environment to no longer function properly [4].

The definition of marine pollution mentioned in [5] that environmental pollution is caused by the marine environment, including the quality, produced and may affect the visibility of marine biodiversity and marine life, human health, disruption to marine activities such as fishing and other marine benefits, decreasing the quality of seawater use and causing discomfort. in the future shipyards will implement green and low-carbon shipments using adequate equipment for implementation.

Pollution in shipyard waters will not only degrade the quality and productivity of the seafloor, moreover, it will affect the quality and productivity of the surrounding waters. This is certainly very detrimental, because the territorial waters of the shipyard and surrounding areas are generally used for other activities such as water recreation, catching waters and aquaculture, as well as around the perry area of PT.X. Therefore, it is necessary to have a dockyard waste management system to maintain the quality of marine waters at a certain level of quality standard that ensures the good quality and high productivity of various marine and sand ecosystems. Responsibility of the shipyard in providing waste collection facilities from ships that will perform repairs using graving dock then followed up, in this case PT. X as a shipyard manager by constructing and operating waste collection facilities.

*Corresponding author: herdis@ui.ac.id 
The orientation to national development has undergone a shift from the concept of land development leading to marine exploration [6]. The shipyard industry in indonsia has been recognized as having the capability and reliable technology in ship building and ship repair. Indonesia's shipbuilding industry is in fact able to build and improve the various types and sizes of ships that have been used by various government agencies, shipping, shipping, offshore construction, TNI and Polri and fishermen. The government, led by President Joko Widodo and Vice President Jusuf Kalla since being inaugurated as president and vice president in 2014, made the Sea Toll Project a priority program to make a solution to the problem of price disparity between the western and eastern regions of Indonesia. Toll sea is a logistics distribution line system that uses ships with scheduled routes from the west to the east and from the north to the south of Indonesia [7]. With the existence of sea toll program will ensure the addition of new ships to meet the needs of the sea Toll. Given the growing number of ships in Indonesia there will be a process of repairing those ships involving the shipyard industry to make improvements.

Development of Workers in environment pollution in PT.X because all workers (Human) is an important thing in environmental coaching the creation of environmentally sound development. Humans engaged in industry and services are very modeled to pollute or not pollute the environment. Education also aims to become human beings who have insight and awareness of the environment with the general public in order to protect and preserve the environment [8]. Decreasing the quality of the environment by human activities There are three factors: the number of people, the amount of nature used by every human being, and the environmental influence of the natural resources used [9]. Based on Miller explanation, there is a relationship between humans, living creatures and the environment.

In the unity of the ecosystem, humans belong to other inseparable elements [10]. Because of that, the sustainability of human life depends on the preservation of ecosystems because humans are very dominant in the effort to preserve the ecosystem, by maintaining the harmony of mutual relationships between humans and the environment so that the ecosystem balance is not disturbed. But if humans maintain their survival at the expense of natural resources based on short-term principles such as to produce as many products as possible with the least possible model, then humans become the main factor of environmental destruction and can threaten human survival [8].

\section{Material and Method}

\section{A. Location and Time of Study}

The research was conducted at PT.X (Industrial Shipyard BUMN). With a focus of research on the process of ship reparations with research time from January to June 2018.

\section{B. Research Stages}

This stage uses literature study and data collection by collecting data related to the research. Locations for sampling were conducted at the repair site of PT.X. The sampling of the research was conducted in the area of ship repair activities, and in other areas. The results of laboratory analysis is used as a reference to determine the level of pollution that is adjusted to the Nasional standard and the established quality standard.

\section{Method of collecting data}

1. Primary data collected by:

a. Survey Method Field observations were conducted to obtain data and information by looking directly at the condition of PT.X (Persero) area.

b. Standard Method of Water Pollution Index Used to be able to know the level of water pollution based on test result in laboratory.

$$
\mathrm{Pl}_{\mathrm{j}}=\sqrt{\frac{\left(\mathrm{C}_{\mathrm{i}} / \mathrm{L}_{\mathrm{ij}}\right)_{\mathrm{M}}^{2}+\left(\mathrm{C}_{\mathrm{i}} / \mathrm{L}_{\mathrm{ij}}\right)_{\mathrm{R}}^{2}}{2}}
$$

Pij: The Standard Index of Water Pollution

Lij: Water Quality Parameter Concentration Included in default Quality of Water Allotment (j)

Ci: Quality Parameter Concentration Water (i)

1. $0=\mathrm{Plj}=1.0$ : meet the quality standard.

2. $1.0<\mathrm{Plj}=5.0$ : mild contamination.

3. $5.0<\mathrm{Plj}=10$ : mild pollen

4. $\mathrm{Plj}>10$ : severe pollutants.

\section{Secondary data collected by:}

a. Survey Method Literature study is a method used to retrieve data from some actual information, writings, books or other literature that comes from competent and related institutions / institutions.

\section{E. Data Analysis}

Data analysis used in this research is physics, chemical and dissolved metal analysis. Further the results of the laboratory can be interpreted with reference to the procedures listed in the environmental quality standard and comparing the handling of dissolved metal / heavy metal wastes $\mathrm{Hg}, \mathrm{Cd}, \mathrm{Cu}, \mathrm{Pb}$ and $\mathrm{Zn}$.

\section{Result and Discussion}

In the ship repair process can cause a negative impact on the environment around the shipyard resulting in decreased environmental quality. Broadly speaking coastal waters in the area of PT.X in quite apprehensive condition. This can be demonstrated from the results of the experiments that have been conducted for water quality in the shipyard PT.X Based on the results of research conducted in PT.X (Persero), can be found the problems as follows: 
Table 1. Environmental Monitoring Result.

\begin{tabular}{|c|c|c|c|c|c|}
\hline \multirow[b]{2}{*}{ No } & \multirow[b]{2}{*}{ Parameter } & \multirow[b]{2}{*}{ Unit } & \multirow{2}{*}{$\begin{array}{c}\text { Quality } \\
\text { Standards }\end{array}$} & \multicolumn{2}{|c|}{ Result } \\
\hline & & & & $\begin{array}{c}\text { In Area } \\
\text { Floating } \\
\text { Dock }\end{array}$ & $\begin{array}{c}\text { In Area } \\
\text { Motor } \\
\text { Boat } \\
\end{array}$ \\
\hline & Physics & & & & \\
\hline 1. & Smell & - & No Smell & $\begin{array}{c}\text { No } \\
\text { Smell }\end{array}$ & $\begin{array}{c}\text { No } \\
\text { Smell } \\
\end{array}$ \\
\hline 2. & Turbidity & NTU & 5 & & 1 \\
\hline 3. & $\begin{array}{l}\text { Suspended } \\
\text { Solids }\end{array}$ & $\mathrm{mq} / \mathrm{L}$ & 80 & 10.5 & 1.50 \\
\hline 4. & Temperature & $\mathrm{OC}$ & Natural & 29,4 & 28,5 \\
\hline 5. & $\mathrm{pH}$ & - & $7-8,5$ & 7,49 & 6,45 \\
\hline & Chemistry & & & & \\
\hline 6. & Salinity & $\mathrm{o} / \mathrm{oo}$ & $33-34$ & 28,5 & 35,1 \\
\hline 7. & $\begin{array}{l}\text { Dissolved } \\
\text { Oxygen } \\
(\mathrm{DO})^{* *}\end{array}$ & $\mathrm{mq} / \mathrm{L}$ & 6 & & 4 \\
\hline 8. & $\mathrm{BOD}_{5}$ & $\mathrm{mq} / \mathrm{L}$ & 20 & & 3 \\
\hline 9. & $\begin{array}{c}\text { Total } \\
\text { Ammonia } \\
\left(\mathrm{NH}_{3}-\mathrm{N}\right)^{* *}\end{array}$ & $\mathrm{mq} / \mathrm{L}$ & 0,3 & 0,4 & 0,043 \\
\hline 10. & $\begin{array}{l}\text { Phospat } \\
\text { (PO-P) }\end{array}$ & $\mathrm{mq} / \mathrm{L}$ & 0,015 & & $<0,01$ \\
\hline 11. & $\begin{array}{c}\text { Nitrate } \\
\left(\mathrm{NO}_{3}-\mathrm{N}\right)\end{array}$ & $\mathrm{mq} / \mathrm{L}$ & 0,008 & & 0,302 \\
\hline 12. & $\begin{array}{c}\text { Cianide } \\
(\mathrm{CN})\end{array}$ & $\mathrm{mq} / \mathrm{L}$ & 0,5 & & $<0,005$ \\
\hline 13. & $\begin{array}{c}\text { Sulfide } \\
\left(\mathrm{H}_{2} \mathrm{~S}\right)\end{array}$ & $\mathrm{mq} / \mathrm{L}$ & 0,01 & $<0,002$ & $<0,002$ \\
\hline 14. & $\begin{array}{c}\text { Total } \\
\text { Phenol } \\
\text { Compounds }\end{array}$ & $\mathrm{mq} / \mathrm{L}$ & 0,002 & $<0,01$ & $<0,001$ \\
\hline 15. & $\begin{array}{l}\text { Surfactan } \\
\text { anion } \\
\text { (MBAS) }\end{array}$ & $\mathrm{mq} / \mathrm{L}$ & 1 & $<0,01$ & $<0,01$ \\
\hline 16. & Oil and Fat & $\mathrm{mq} / \mathrm{L}$ & 1 & $<0,2$ & $<0,2$ \\
\hline & $\begin{array}{c}\text { Precious } \\
\text { Metal }\end{array}$ & & & & \\
\hline 17. & $\begin{array}{l}\text { Mercuty } \\
(\mathrm{Hq})\end{array}$ & $\mathrm{mq} / \mathrm{L}$ & 0,003 & $<0,005$ & $<0,0005$ \\
\hline 18. & $\begin{array}{l}\text { Arsenic } \\
\text { (As) }\end{array}$ & $\mathrm{mq} / \mathrm{L}$ & 0,05 & & $<0,002$ \\
\hline 19. & $\begin{array}{l}\text { Chromium } \\
\text { VI }\left(\mathrm{Cr}^{6+}\right)\end{array}$ & $\mathrm{mq} / \mathrm{L}$ & 0,005 & & $<0,01$ \\
\hline 20. & $\begin{array}{c}\text { Cadmium } \\
(\mathrm{Cd})^{* *}\end{array}$ & $\mathrm{mq} / \mathrm{L}$ & 0,001 & $<0,01$ & 0,0009 \\
\hline 21. & $\begin{array}{l}\text { Copper } \\
(\mathrm{Cu})^{* *}\end{array}$ & $\mathrm{mq} / \mathrm{L}$ & 0,008 & 1,96 & 0,003 \\
\hline 22. & $\begin{array}{l}\text { Lead } \\
(\mathrm{Pb})^{* *}\end{array}$ & $\mathrm{mq} / \mathrm{L}$ & 0,008 & 0,08 & 0,02 \\
\hline 23. & Zink (Zn) & $\mathrm{mq} / \mathrm{L}$ & 0,05 & $<0,01$ & 0,03 \\
\hline 24. & Nickel (Ni) & $\mathrm{mq} / \mathrm{L}$ & 0,05 & & 0,0007 \\
\hline
\end{tabular}

\section{A. Trend Evaluation}

The results of the laboratory measurements show that most of the surface water quality parameters are below the quality standard in accordance with the Decree of the
State Minister of Environment No. 51 of 2004 but the parameters of surface water quality there are several parameters above the quality standard that is:

1. Salinity (level of salinity) of 35.1 is above the standard due to the greater evaporation, location and size of the sea that are not related to the river, ocean currents that are affected by heat and wind due to air humidity.

2. Nitrate $\left(\mathrm{NO}_{3}-\mathrm{N}\right)$ of 0.302 is above the standard quality caused by the sinking of particles containing excessive phosphate elements.

3. Lead $(\mathrm{Pb})$ of 0.08 and Lead $(\mathrm{Pb})$ of 0.02 is above the standard due to the amount of dissolved metal content in the water.

\section{B. Critical Level}

1. Increasing the content of $\mathrm{NO}_{3}$ in waters in quantities that exceed the quality standard may cause adverse effects to the organism as it will accumulate excess algae growth resulting in water shortage of $\mathrm{O}_{2}$.

2. Content of $\mathrm{Pb}$ that exceeds the quality standard in the waters of the floting dock area near the ship repair site that is the remains of the hull washing process.

From ship reparation process conducted at PT. X which has the potential to pollute the environment that requires efforts for environmental management and monitoring for some environmental components. PT. X has made several environmental management efforts on the ship repair process.

1. The K3 and Environment Division continues to improve and update environmental management procedures.

2. Improving the ability of discipline in doing the job.

3. Implement AMDAL to know the changing of environmental quality for each period.

Basically PT. X has compiled the policies according to the procedure but in fact can not be applied optimally because of the various interests that do not care about the applicable procedures that can lead to decreased quality of the environment. Therefore, in environmental management in PT.X, it needs to be implemented in an integrated and comprehensive manner that is related or not to achieve harmony and balance between human beings with environmental carrying capacity for the benefit of present and future generations.

1. Based on the analysis of seawater quality at PT. X conducted using water pollution index method can be concluded that the waters at PT. X in contaminated state. Concentrations of heavy metals exceed the quality standards found on two stations.

2. Some procedures and policies have been implemented by PT. X but, in fact not going well because it still requires development in the company's management system in environmental management. The policies that have been arranged are not based on the priority scale by taking into account various factors that include the supporting factors as well as the inhibiting factors where the increase of reparations made at $\mathrm{PT}$. X will increase the waste that will be generated. 
3. Priority strategy is a priority enhancement and coordination mechanism in implementing operational standard procedures and controlling waste pollution by applying waste management procedures.

\section{Conclusion}

Based on the results of research that has been done to reduce the negative impact caused by the ship repair activities and plans for the development of the environment, especially in PT. X then required:

1. The strategy resulting from this research is applied and can be taken into consideration in determining the direction of environmental management, especially for the shipyard industry which makes the coastal area become the place of ship repair.

2. Grow awareness to all concerned and unrelated parties to care for the environment by managing waste from ship repairs in order to minimize the risk of environmental pollution and harm the ecosystem and natural resources,

This research is funded by the Grant of Indexed International Publication for Final Project of Students/Publikasi Terindeks Internasional Untuk Tugas Akhir Mahasiswa (PITTA) Universitas Indonesia 2018 with contract number 2578/UN.R3.1/HKP.05.00/2018

\section{References}

1. Abdul Rahman \& Heri Supomo. (2012). Customer Satisfaction Analysis On Ship Repair Works With Quality Function Deployment (QFD) Method.

2. Budiyanto, A. (2016). Environmental Insurance Model in Shipyard Industry.

3. Saeni MS. (1989). Chemical environment. Bogor: Center for Inter-University Studies. Biological Science of IPB

4. Law no. 23 of 1997 on Environmental Management.

5. UNCLOS III ( Third United Nations Convention on the Law of the Sea = UN.DocA/Conv. 62/122. Entering into force on November 16, 1994)

6. Aulia, W. (2008). Prospect of Domestic Shipbuilding Industry To Face Global Competition.

7. Andilas \& Liana. (2017). Implementation of PT.Pelayaran Nasional Toll Sea Indonesia Program.

8. Suwardi (2008). Effect of Ship Visits and Utilization of Reception Facilities on Port Quality Waters. Thesis. University of Indonesia.

9. Miller, G. T. \& Spoolman. (2015). Environmental science. Dan Fitzgerald, Graphic World Inc.

10. Hambali, I. (2004). Ecoport: Government Policy on Revitalization of Liquid Waste Storage Facility at Port (Case Study at Port of Tanjung Perak Surabaya in Bandar Indah Program Framework). Thesis. University of Indonesia. 